IRSH 53 (2008), pp. 395-423 doi:I0.1017/So020859008003532

(C) 2008 Internationaal Instituut voor Sociale Geschiedenis

\title{
Was the Personal Political? Reading the Autobiography of American Communism*
}

\author{
JAMES R. B A R RETT
}

SUMMARY: Taking the communist memoir as a sub-genre of working-class autobiography, the article analyzes, first, the characteristics of the communist autobiography, the conditions under which such works were produced, and their intended functions. Second, the article considers some personal dimensions of American communist history and how this more subjective side of the history relates to the more familiar political narrative of the movement. Recent feminist and other theory of autobiography are employed to analyze approximately forty communist autobiographies and other personal narrative material to analyze personal love and marriage, child rearing and family life, and self-identity within the party.

\section{INTRODUCTION}

Amid calls for global approaches to the study of history, some labor historians have turned to the more personal dimensions of working-class life through the study of biography and autobiography. While an emphasis on social process, collective experience, and material conditions has largely defined social history for a generation, recent theory, the decline of the labor movement, and political transformations have encouraged some to consider the more subjective aspects of working peoples' lives. At the same time, the history of American communism has enjoyed a renaissance, with a new generation of anti-communist scholars contending with aging $\mathrm{New}$ Left interpreters over the meaning of communism in the broader sweep of US history. One contention concerns the very nature of the Communist Party USA (CPUSA). The new anti-communists have documented at length the espionage activities of party members and have returned us to a

\footnotetext{
* Earlier versions of this paper were presented at the Social Science History Association Conference, Chicago, November 2004, the Congress of International Historical Sciences, Sydney, Australia, July 2005, and the North American Labor History Conference, Detroit, October 2005. I am grateful to commentators and discussants at these conferences, to the journal's board and three anonymous readers for the IRSH, and especially to Glenda Gilmore, Marilyn Booth, Kathy Oberdeck, Leslie Reagan, and Diane Koenker for their comments and to Nciole Ranganath, Adam Hodges, and Caroline Merithew for their research assistance.
} 
view of the party as essentially a tool of the Soviet state, while leftist interpreters argue that it represented a genuine social movement shaped by domestic situations. Rather than the influence of Stalinism, New Left historians have tended to emphasize the agency of party members. ${ }^{\mathrm{I}}$

Historians of the Left and the movement itself have long compiled biographical data on leading communists. An important international biographical turn in the history of communism is represented by Kevin Morgan and the group of scholars working at the University of Manchester, where they have constructed a very large data base of biographical information on individuals associated with the Communist Party of Great Britain. Some of their published work has included biographical essays on figures from various national parties. ${ }^{2}$ For the most part, however, even this work has employed biographical materials as data on which to generalize about the characteristics of party militants, largely steering clear of the personal and emotional issues addressed in this article. Likewise, biographies of several of the most important leaders in the American party over the past decade have dealt with their subjects' personal lives. The object of these studies, however, has been to assess their subjects' impact on the political movements they helped to build. ${ }^{3}$ Most historians in the United

I. See Harvey Klehr, "The Historiography of American Communism: An Unsettled Field", Labour History Review, 68 (2003), pp. 6I-78; and for a criticism of much of the left-wing scholarship for underestimating the influence of Stalinism in the party's history, Bryan Palmer, "Rethinking the History of United States Communism", American Communist History, 2 (2003), pp. I39-173, with responses by John Earl Haynes, James R. Barrett, Melvyn Dubofsky, and John McIlroy, pp. 175-202. For unusual treatments of sexuality, personal relationships, and the emotional content of communist activism, which have influenced my own approach here, see Kathleen A. Brown and Elizabeth Faue, "Social Bonds, Sexual Politics, and Political Community in the US Left, I920s to I940s", Left History, 7 (2000), pp. 9-45; idem, "Revolutionary Desire: Redefining the Politics of Sexuality of American Radicals, 1919-1945", in Kathleen Kennedy and Sharon Ullman (eds), Sexual Borderlands: Constructing an American Sexual Past (Columbus, OH, 2003), pp. 273-302.

2. See John McIlroy, Kevin Morgan, and Alan Campbell (eds), Party People, Communist Lives: Explorations in Biography (London, 2001), and Kevin Morgan, Gidon Cohen, and Andrew Flinn (eds), Agents of the Revolution: New Biographical Approaches to the History of International Communism in the Age of Lenin and Stalin (Oxford, 2005). For collective biography as a data base for the movement's history, see "The CPGB Biographical Project", and Peter Huber, "Working on a New Biographical Dictionary of the Comintern: A Survey", paper presented at the conference, "People of a New Mould?", University of Manchester, 6-8 April 200 I. The collection of biographical data on party militants is, of course, an old Soviet tradition. See Diane Koenker, "Scripting the Revolutionary Worker Autobiography: Archetypes, Models, Inventions, and Markets", International Review of Social History, 49 (2004), pp. 371-400.

3. Edward J. Johanningsmeir, Forging American Communism: The Life of William Z. Foster (Princeton, NJ, 1994); James G. Ryan, Earl Browder: The Failure of American Communism (Tuscaloosa, AL, 1997); James R. Barrett, William Z. Foster and the Tragedy of American Radicalism (Urbana, IL, I999); Bryan D. Palmer, James P. Cannon and the Origins of the American Revolutionary Left, I890-1928 (Urbana, IL, 2007). 
States and elsewhere continue to think about communism with what Vivian Gornick, writing more than thirty years ago, called "an oppressive distance between themselves and their subjects", which "conveys only an emotional and intellectual atmosphere of 'otherness' - as though something not quite recognizable, something vaguely nonhuman was being described". ${ }^{4}$ What might be called the subjective history of communism tells us a good deal about the costs and also the attractions of the movement. The ideological and organizational character of communist parties might remain paramount in the writing of their histories, but the history of the subjective lends a personal dimension to the phenomenon that a strictly political reading of communism cannot grasp.

This essay draws on about forty communist and former communist memoirs, in addition to interviews and other forms of personal narrative. What can these texts tell us about the personal identity and intimate relationships within the party and about the gendered quality of the communist experience? In the process of answering this question, I hope to encourage the notion among social historians that our worker-subjects were individuals, as well as members of a social class, and that they traveled through their historical experiences with emotional and personal baggage that bear a relationship to the sensibilities and feelings that govern a good part of our own lives. Taking the communist memoir as a sub-genre of working-class autobiography, I first analyze the characteristics of the communist autobiography, the conditions under which such works were produced, and their intended functions. In the second portion of the paper I ask, was there a personal dimension to the history of American communism and if so, of what does this history consist and how does it relate to the more familiar political narrative of the movement?

\section{WORKING-CLASS AUTOBIOGRAPHY AND COMMUNIST AUTOBIOGRAPHY}

An autobiography represents, not the unmediated story of a person's actual experience, but rather a constructed narrative full of conscious and unconscious choices on the part of its author. The notion that autobiographies are based on available models and shaped by the conditions under which they were produced and the goals they were intended to achieve represents a well-established understanding of what we mean by

4. Vivian Gornick, The Romance of American Communism (New York, 1977), p. i8. The forty-seven interviews excerpted in Gornick's book are identified only by pseudonym and she includes only a very brief description of her anecdotal methods. But hers is by far the most ambitious treatment of the subjective dimensions of Communist Party activism. Many of her respondents are identifiable to someone familiar with the party's history and communist autobiography. 
the term. ' Autobiography, Phillipe LeJeune concludes, "is necessarily in its deepest sense a special kind of fiction, its truth as much created as discovered realities". Indeed, Joan Scott has gone so far as to argue that the "experience" of our historical subjects is itself a notion constructed by historians to provide a universalized understanding of the past, that "experiences" are themselves socially and culturally constructed. ${ }^{6}$

Autobiography appears by definition to be the province of the "sovereign self", "the genre par excellence of the emergent bourgeoisie", as Mary Jo Maynes has noted. Often traced back to Rousseau and Goethe, "It was the literary expression of individualism, and the faith in an integrated and coherent personality so central to the bourgeois economic and political philosophy that was groping its way to prominence $[\ldots]$ part of the broader historical creation of the bourgeois personality." 7 The rare worker-autobiographer was, in this sense, "atypical" by virtue of having become a more or less self-reflective writer. They were what Maynes calls "boundary crossers", living their lives in working-class communities and often expending their energies and talents in creating and shaping working-class social and political movements, but also observing their own lives and those of their class-mates from a reflective perspective that owed something to bourgeois autobiographical traditions. ${ }^{8}$

Yet we must analyze proletarian autobiographers differently than we might their bourgeois counterparts. Scholars of working-class autobiography have long stressed its tendency to diminish or dissolve the self, to ignore the personal dimension of experience in favor of the collective, to stress the "ordinary" quality of its subjects. The convention of the

5. My own understanding of autobiography differs somewhat from current postmodern notions of the genre, but my approach has been shaped in various ways by works in the following two notes, as well as by some of the essays in Sidonie Smith and Julia Watson (eds), Women, Autobiography, Theory: A Reader (Madison, WI, 1998) and especially George Steinmetz, "Reflections on the Role of Social Narratives in Working-Class Formation: Narrative Theory in the Social Sciences", Social Science History, I6 (I992), pp. 489-5 I6.

6. Reginia Gagnier, "The Literary Standard, Working-Class Autobiography, and Gender”, in Susan Groag Bell and Marilyn Yalom (eds), Revealing Lives: Autobiography, Biography, and Gender (Albany, NY, 1990), p. 94; Joan Scott, "Experience", in Judith Butler and Joan Scott (eds), Feminists Theorize the Political (New York, 1992), pp. 22-40; quotation, Phillipe LeJeune, On Autobiography, ed. with a forward by Paul John Eakin, trans. Katherine Leary (Minneapolis, MN, I989), p. ix.

7. Mary Jo Maynes, "Gender and Narrative Form in French and German Working-Class Autobiographies", in Personal Narratives Group, Interpreting Women's Lives: Feminist Theory and Personal Narratives (Bloomington, IN, I989), p. I04. See also, Sidonie Smith and Julia Walton, Reading Autobiography: A Guide for Interpreting Life Narratives (Minneapolis, MN, 200I), pp. 2-4, and James Olney, Metaphors of Self: The Meaning of Autobiography (Princeton, NJ, I972).

8. Mary Jo Maynes, Taking the Hard Road: Life Course in French and German Workers' Autobiographies in the Era of Industrialization (Chapel Hill, NC, I995), p. 200. 
individual as "social atom", as Reginia Gagnier notes, serves to distinguish working-class autobiography from the more introspective bourgeois genre. ${ }^{9}$ This tendency has been particularly marked in the case of labor and socialist activists for whom the central narrative seems always to be focused first on one's "conversion" to the movement and then on the development of the party or movement itself, rather than on the individual. ${ }^{10}$

Within the broader field of working-class autobiography, communist personal narratives would seem particularly problematic. Any sort of biographical approach might even seem superfluous because the movement's "proverbial conformism, intrusiveness and monolithicity were backed up by the strictest codes of party discipline". II Add to this the strong political interests of most historians of communism, regardless of political affiliation, and common assumptions about the character of communist parties and their negative effects on individual agency and autonomy, and there is little if any room left for the person or the personal in the history of communism. ${ }^{12}$ In describing the assumptions of most historians of communism, Kevin Morgan, a biographer of British communists, argues, "The historiography of communism is predicated on a group identity so intense and pervasive as to leave little room for distinctive life histories." All experience and thought is assumed to be "subordinate to the totalitarian logic of party discipline". ${ }^{13}$

Thus, few historians of any political description have been inclined to think about the autobiographical dimension of communist history. Communist autobiographers have included many middle-class authors, but their commitment to a working-class political organization and the collective quality of that commitment have discouraged the discussion of subjective experience in most of their personal narratives as well. Communist writers have eschewed the personal, focusing instead on the

9. Reginia Gagnier, "Social Atoms: Working-Class Autobiography. Subjectivity, and Gender", Victorian Studies, 30 (1987), pp. 335-362. On working-class autobiography as a distinct genre requiring a different analytical approach, see also John Burnett, David Vincent, and David Mayall (eds), The Autobiography of the Working Class: An Annotated Critical Bibliography, I (New York, 1984), pp. xvii-xxix; Maynes, Taking the Hard Road, p. 33; Gagnier, "The Literary Standard, Working-Class Autobiography, and Gender”, pp. 93-II4; Koenker, "Scripting the Revolutionary Worker Autobiography", pp. 371-373.

I0. Maynes, Taking the Hard Road, pp. 200, I 54. The emphasis on a conversion that reorients the life narrative around this new central commitment means that communist autobiography bears some resemblance to Christian "conversion narratives" which have received considerable attention from scholars of autobiography. See Smith and Watson, Reading Autobiography, pp. 70, 85, I01, I92-93.

I I. Kevin Morgan, "Parts of People and Communist Lives", in McIlroy, Morgan, and Campbell, Party People, Communist Lives, p. Iо.

I 2. Interestingly, the central message of the six existential personal narratives in Richard Crossman's extremely popular collection, The God that Failed (New York, 1950) is that there is no room for the individual in the communist movement.

I3. Morgan, "Parts of People and Communist Lives", pp. Iо, I I, I 2. 
party; the personal story was only significant in so much as it shed light on the evolution of the organization, its successes and failures, or broader lessons for communists and other radicals. Anti-communist writers have been particularly disinclined to dwell on the personal because they have viewed the party largely as an extension of the Soviet state - a monolithic, totalitarian instrument of a foreign power in which personal experience tells us little if anything about the history. ${ }^{\mathrm{I}}$ New Left historians of American communism have shown greater interest in the personal dimension of the story, perhaps because of their own roots in a political tradition claiming that "the personal is political". ${ }^{\text {Is }}$ But even many of the New Left scholars of communist biography have tended to be more concerned with the political dimension than with their subjects' personal lives. ${ }^{16}$

Yet the study of individual communist lives offers us what Morgan sees as

$[\ldots]$ a way to move beyond traditional party historiographies $[\ldots]$ to an altogether more complex, nuanced and unsettling account [...]. If relating such stories constitutes revisionism, it is simply in the sense of a populated history, fragmented enough to embrace the extraordinary diversity of experiences it encompassed over the three-quarters of a century. ${ }^{17}$

In part, then, we pursue communist autobiography to "populate" our histories with flesh-and-blood subjects, not the cardboard characters that filled the scenery in older political histories of the movement. Given the strength of Cold War caricatures re-emerging in the American historiography, this in itself is a contribution. It is more difficult to ignore the basis for communist loyalties in the everyday experiences of working-class people and others - to objectify individual identity in the name of a vast faceless international conspiracy - when we confront the diversity in human experience contained in personal narratives. In the context of the American historiographical debates, an approach based on autobiographies makes it

14. The roots of this approach lie in the seminal work of Theodore Draper: The Roots of American Communism (New York, 1957); and idem, American Communism and Soviet Russia (New York, 1960; 2nd edn, New York, 1986). Draper's interpretation is carried on in the work of Harvey Klehr and John Earl Haynes. See Harvey Klehr and John Earl Haynes, The American Communist Movement: Storming Heaven Itself (New York, 1992); Harvey Klehr, Heyday of American Communism: the Depression Decade (New York, 1984). For Draper's assessments of the New Left scholarship, see Theodore Draper, "American Communism Revisited", New York Review of Books, 9 May 1985, pp. 32-37; idem, "The Popular Front Revisited", New York Review of Books, 30 May I985, pp. 79-8I.

I s. Sara Evans, Personal Politics: The Roots of Women's Liberation and the New Left (New York, 1979).

I6. For the tension between the New Left historians and their Old Left subjects over personal issues, see Nell Painter, The Narrative of Hosea Hudson: His Life as a Negro Communist in the South (Cambridge, MA, 1979), pp. 36-37, 39-40, and Ellen Kay Trimberger, "Women in the Old and New Left: The Evolution of a Politics of Personal Life", Feminist Studies, 5 (1979), pp. 432-449. 17. Morgan, "Parts of People and Communist Lives", p. 23. 
more difficult to sustain the image of American communists as a collection of Soviet automatons. In this sense too the personal side of communist history is political. Indeed, a great deal in the history of American communism is lost in deciding that the personal experiences of these activists are not a significant part of that story.

\section{AUTOBIOGRAPHIES OF AMERICAN COMMUNISM}

In fact, communist activists could speak in a different, more personal voice, given the right setting. Personal diaries might be one example, intimate correspondence with family or close friends another. Published autobiographies, however, are quite public by their nature and we can employ them only very carefully, considering their purposes, the conditions under which they were produced, and their broader social and political contexts. ${ }^{18}$

In the case of the United States, a substantial set of autobiographies constitutes a base for such an analysis. We have several distinct genres, in fact, of communist personal narratives. The first of these was fundamentally shaped by the party itself. As in the case of most national parties, the CPUSA published numerous party autobiographies. Even more than most workers' personal narratives, these tend to be narrowly didactic texts geared to the party's own interests, useful primarily for clues as to how the party viewed such individuals, as well as for the details of organizational life they might convey. ${ }^{19}$ The party's own autobiographies

18. For particularly striking American cases, see the voluminous prison correspondence between veteran communist activist Gil Green and his wife and children between 1957 and 1963 and the wartime correspondence between Bill Dunne and his wife Marguerite; Gil Green Papers, Chicago Historical Society, Box I; William F. Dunne Papers, Tamiment Institute, New York University, Box I, Folders io, I I.

19. Hosea Hudson, Black Worker in the Deep South: A Personal Record (New York, 1972); William Patterson, The Man Who Cried Genocide (New York, 197I); Benjamin Davis, Communist Councilman from Harlem: Autobiographical Notes Written in a Federal Penitentiary (New York, I969); Jack Kling, Where the Action Is: Memoirs of a US Communist (New York, 1986); John Williamson, Dangerous Scot: The Life and Work of an American 'Undesirable' (New York, 1969); Elizabeth Gurley Flynn, I Speak My Own Piece: Autobiography of the Revel Girl (New York, 1955), and idem, The Alderson Story: My Life as a Political Prisoner (New York, 1963); William Z. Foster, From Bryan to Stalin (New York, 1937), and idem, Pages from a Worker's Life (New York,1939); Art Shields, On the Battle Lines, 1919-1939 (New York, 1986); Charles R. Rubin, The Log of Rubin the Sailor (New York, 1973); Ella Reeve Bloor, We Are Many (New York, 1940); Gil Green, Cold War Fugitive (New York, 1985). Joseph Freeman's An American Testament (New York, 1936), the work of an accomplished writer published by a large commercial press, differs markedly from most other party biographies. Yet Freeman's central narrative is his gradual maturity as a communist intellectual. I have also read several unpublished autobiographies that seem to fit in this category, despite the fact that their authors were all expelled from the party before they sat down to write: Max Bedacht, Alexander Bittelman, William Dunne, and Samuel Darcy, all in the authors' manuscript collections at the Tamiment Institute, Bobst Library, New York University. 
represent particularly striking examples of the constructed nature of personal narratives. Indeed, the narrative decisions were not simply made by the individual authors, but were deeply influenced by the party. Given the constructed nature of autobiographies, scholars of the genre stress the significance of the models autobiographers might have taken, consciously or subconsciously, in shaping their own stories. Here Soviet autobiography likely played a vital role. As in so many other aspects of party life, American communists seemed to shape their own personal narratives with Soviet models in mind..$^{20}$ But the intervention of other voices in the narrative could also be far more direct. Written under party direction and editing, and sometimes even subject to committee assessment, such autobiographies fulfilled several vital functions.

First, they conveyed lessons for revolutionaries. Particular episodes were developed to demonstrate such lessons. The party's most popular autobiographies, by Elizabeth Gurley Flynn and William Z. Foster, for example, were less narratives than collections of brief sketches, each intended to make a particular point about the experience of being a revolutionary worker. ${ }^{2 \mathrm{I}}$

Party autobiographies also provided models of revolutionary commitment and genius. The Nicaraguan revolutionary Manuel Calderon captured their importance as vivid symbols of the revolutionary party. A scientific theory such as Marxism-Leninism provided a useful guide, he noted, but "in real life, it is the concrete, personal example that motivates people". ${ }^{22}$ None of this means that such model narratives were identical in content. Even in party autobiographies, women tended much more than men to include personal details about family and children, love and friendship relations, and even emotions. The contrast in the autobiographies of Foster and Flynn is striking in this regard. Both were Irish-American radicals who came out of the IWW with strong attachments to the labor movement and both joined the Communist Party in middle age. Flynn includes extensive details about her first unsuccessful marriage, a miscarriage, the death of her infant child,

\footnotetext{
20. Steinmetz, "Reflections on the Role of Social Narratives in Working-Class Formation". On Soviet workers' autobiography, especially the conditions of its production and the significance of available models, see Koenker, "Scripting the Revolutionary Worker Autobiography", pp. 37I-400, which has had an influence on my analysis of the American autobiographies.

2 I. Foster, From Bryan to Stalin; Foster, Pages from a Worker's Life; Gurley Flynn, I Speak My Own Piece; The Alderson Story. Both autobiographers focus heavily on their lives before joining the party, yet the narratives are organized around specific movement activities and the lessons drawn from these. Foster, in particular, organizes his stories around problems for which the Communist Party ultimately provided the solution. See James R. Barrett, "Revolution and Personal Crisis: William Z. Foster, Personal Narrative, and the Subjective in the History of American Communism", Labor History, 43 (2002), pp. 472-475. See also the autobiographies cited in n. I I.

22. Heyck, Life Stories of the Nicaraguan Revolution, p. I22, quoted in Camilla Stivers, "Reflections on the Role of Personal Narrative in Social Science", Signs: Journal of Women in Society and Culture, I8 (1993), p. 4I9.
} 
and her long-term love relationship with the Italian anarchist, Carlo Tresca. (Interestingly, Flynn includes no details at all about her ten-year lesbian relationship with the radical physician and birth control advocate Marie Equi, suggesting, apparently, the limits of party tolerance for the personal.) Flynn's sister Kathy, her parents, her son Fred, and her lover Tresca glide in and out of the story. In contrast, Foster's first autobiographical volume includes no mention at all of his first marriage, little on his family background, and only brief mention of his wife, and in his second volume, no mention of her at all. ${ }^{23}$

Why women militants' narratives tended more toward the personal is an interesting question. Scholars of autobiography tells us that writers construct their personal stories on the basis of models and values close at hand and are deeply influenced by the conditions under which they produce their texts. It seems likely, then, that women activists, however radical they might appear by the standards of their time, were nevertheless influenced by some of the same values that shaped other women's autobiographies - a greater value on personal relationships, greater attention to the family, for example. ${ }^{24}$

These autobiographies, organized around a strong central narrative of party-building and class conflict, provided more than lessons. In the process of telling an individual's life story, they told the party's own. These were, in a real sense, histories of the working-class movement writ small, on a human scale, so that they conveyed a narrative of heroic struggle and a steady march toward the party as the ultimate instrument of working-class liberation. Indeed, William Z. Foster observed that his autobiography was less a personal narrative than "[a] contribution to the history of left trade unionism in the United State during the past forty years", and an "outline of the development of the Communist Party".2s But because of their human scale, such narratives also provided model lives for individual militants.

What scholars of autobiography have come to call "conversion narratives" play a critical part in many of these autobiographies. The early narrative is often filled with details of poverty and disorganization that underline the misery of working-class life under capitalism, providing the

23. On the peculiarly homo-social masculine character of Foster's narrative, see Barrett, "Revolution and Personal Crisis", pp. 475-476; on the masculine quality of the party's appeal in the I920s and I930s, Van Gosse, "To Organize in Every Neighborhood, Every Home: The Gender Politics of American Communists between the Wars", Radical History Review, 50 (I99I), pp. I09-I42; and on Flynn's long relationship with Equi, Rosalyn Fraad Baxandall, Words on Fire: The Life and Writings of Elizabeth Gurley Flynn (New Brunswick, NJ, 1987), and Brown and Faue, "Revolutionary Desire", p. 288.

24. Germaine Bree, "Autobiography", in James Olney (ed.), Studies in Autobiography (New York, I988), pp. I7I-I79.

25. Foster, Pages from a Worker's Life, p. I I. 
material basis for class consciousness and the search for a political way out. The narrative builds to a moment of conversion to socialism and then marches through a process of movement building in which the author is important only insofar as her/his story helps to explain the development of the party and its fate. Writing of similar conversions in French and German socialist autobiographies, Mary Jo Maynes notes that,

$[\ldots]$ these moments signify the point when the plots of their life stories were revealed to their heroes or heroines [...]. Through the reconstruction of these transformative moments, authors reconstructed the process by which they came to imagine and pursue possibilities for themselves other than ones to which had seemingly been born. ${ }^{26}$

As Nell Painter wrote of her experience working with the Black communist Hosea Hudson on his personal narrative, "Hudson spoke as if his life were divided into forty-six years in the Communist Party and thirty-five years groping toward it". ${ }^{77}$ William Z. Foster's account is more or less typical of male autobiographers. He was walking the streets of his native Philadelphia slum in the summer of 1900 when he encountered a street corner Socialist speaker: "His arguments and analysis seemed to give real meaning to all my experience in the class struggle $[\ldots]$ I began to count myself, from that time on, a Socialist. That street meeting marked a turning point in my life." Though the Communist Party was not born until nearly two decades later and Foster did not join until I92I, the remainder of his story is organized around his ideological journey from socialism through syndicalism to Marxism-Leninism. ${ }^{28}$

Though they might experience their own dramatic conversions, women militants were more often what American communists came to call "reddiaper babies", encountering the movement within their own families. ${ }^{29}$ Peggy Dennis, Dorothy Healey, and Elizabeth Gurley Flynn were all born into socialist families and raised within the movement. An alternative route came through the rebellion of upper-class children, as in the case of Jessica Mitford, who first joined the Communist Party of Great Britain and ran off to Spain in the late I930s, even as her parents and sisters cultivated their relations with high-ranking Nazis and developed alliances with home-grown British fascists. Mitford later became a local party activist

26. Maynes, Taking the Hard Road, p. I 54 .

27. Painter, The Narrative of Hosea Hudson, p. 2.

28. Foster, From Bryan to Stalin, p. 23. For a fuller analysis of Foster's autobiographical writing in the context of his political career, see Barrett, "Revolution and Personal Crisis". See also Paul F. Douglas, Six Upon the World: Toward an American Culture for an Industrial Change (Boston, MA, I954), p. 68.

29. Judy Kaplan and Linn Shapiro (eds), Red Diapers: Growing up in the Communist Left (Urbana, IL, 1998). Phil Cohen (ed.), Children of the Revolution (London, 1997) represents a comparable collection for the children of British communists. 
and organizer for the Civil Rights Congress in the San Francisco Bay area and eventually, after leaving the party, a best-selling author. ${ }^{3 \circ}$

A second genre of anti-communist narratives, what might be called "confessional anti-memoirs", were particularly significant in the context of the Cold War when the government sought to discredit domestic radicalism and much of the public was eager for lurid renditions of communist treachery and subversion..$^{31}$ These texts have a central plot every bit as pronounced as the party autobiographies - the subversion of American democracy and its displacement by a mindless commitment to Soviet totalitarianism. Such texts can be useful for conveying the seamier dimensions of communist experience that one is unlikely to find in authorized party biographies, but their intended political functions and the antagonistic frame of mind with which the authors took up their pens underscore the limits within which any autobiography, and certainly these, can be read as objective accounts of "experience". Virtually all of these memoirs focus particularly on their authors' and other communists' roles in Soviet espionage activities, an experience of particular concern in much of the older and more recent anti-communist historical writing but one quite foreign to the lives of most rank-and-file American communists. ${ }^{32}$

30. Flynn, I Speak My Own Piece; Peggy Dennis, The Autobiography of an American Communist: A Personal View of a Political Life, 1925-1975 (Westport, CT, 1977); Dorothy Healey and Maurice Isserman, Dorothy Healey Remembers: A Life in the American Communist Party (New York, I990); Jessica Mitford, A Fine Old Conflict (New York, 1977); Mary S. Lovell, The Mitford Girls: The Biography of an Extraordinary Family (Boston, MA, 200I). For a similar observation regarding the political socialization of French and German women radicals, see Maynes, Taking the Hard Road, pp. I59-163.

3. Benjamin Gitlow, I Confess, The Truth about American Communism (New York, 1940) and idem, The Whole of Their Lives: Communism in America - A Personal History and Intimate Portrayal of Its Leaders (New York, 1948); Louis Francis Budenz, Men Without Faces: The Communist Conspiracy in the United States (New York, 1948); Whittaker Chambers, Witness (New York, I952); Elizabeth Bentley, Out of Bondage: The Story of Elizabeth Bentley (New York, 195 I); Bella Dodd, School of Darkness (New York, 1954). On confessions as an autobiographical genre going back to Rousseau, see Rita Felski, "On Confession", in Women, Autobiography, Theory: A Reader (Madison, WI, 1998), pp. 83-95. Felski's analysis is particularly relevant for the confessions of women apostates, which tend to include more personal material. See also Smith and Watson, Reading Autobiography, pp. 85, 146-147, 192. For an early "anti-memoir", see Fred Beal, Proletarian Journey: New England, Gastonia, Moscow (New York, 1937). A leader of the party's 1929 Gastonia, North Carolina strike, Beal fled prosecution by living in the Soviet Union for several years, an experience that led him to break with the party.

32. Harvey Klehr and John Earl Haynes, In Denial: Historians, Communism and Espionage (San Francisco, CA, 2003) argues for the centrality of espionage to the communist experience and the failure of many New Left historians to engage this dimension of communist history. On the role of espionage, see Harvey Klehr, John Earl Haynes, and Fridrikh Iforevich Firsov, The Secret World of American Communism (New Haven, CT, I995); Harvey Klehr and Ronald Radosh, The Amerasia Spy Case: Prelude to McCarthyism (Chapel Hill, NC, 1996); Harvey Klehr, John Early Haynes, and Kyrill M. Anderson, The Soviet World of American Communism (New Haven, CT, 1998); John Earl Haynes and Harvey Klehr, Venona: Decoding Soviet Espionage in America (New Haven, CT, 2002). 
Finally, an interesting group of "oral biographies" produced between the late I970s and the early I990s were often the products of collaboration between communist veterans and younger scholars, dialogues of sorts between the Old and New Lefts. Several of these autobiographies constitute among our best cases of the integration of politics with personal experience. Most of these veterans had left the party or been expelled either during the 1956-1957 crisis at the time of Khrushchev's revelations and the invasion of Hungary or during the next major party crisis with the Soviet invasion of Czechoslovakia in $1968 .{ }^{33}$ Although some of these veterans undertook their writing independently, much of this work took the form of oral history shaped by the political backgrounds of both the New Left historians and their respondents. The human dimension of American communism looms larger in many of these projects, and some of them involve what Camilla Stivers has called a "subject-to-subject" approach in which the interviewer/author is aware of his/her own perspective and interests in producing the book. ${ }^{34}$

One of the most important documentary films dealing with the party's history, based on extensive interviews, was produced with the explicit aim of putting a human face on the American communist movement. ${ }^{35}$ Many of the New Left historians were shaped by a movement that held that the personal was indeed political, and they consciously investigated their subjects' personal lives in the course of researching, interviewing, writing, and editing the narratives. Raised in the Cold War and committed to fundamental social change, such historians sought in part to humanize a movement they had been taught to hate. Even in these cases, however, the narrative is often driven by the veterans' tendencies to discount personal experience and identity as secondary to the main plot of political organization and conflict, and by New Left scholars' own political agendas which often involved the search for a "usable" historical past. The pursuit of the relationship between the personal and the political was particularly strong among feminist historians whose approach was formed in the context of the new women's movement of the late ig6os and early i 970 s. $^{36}$

33. John Gates, The Story of an American Communist (New York, I958); George Charney, $A$ Long Journey (Chicago, IL, I968); Al Richmond, A Long View from the Left (New York, I972); Vera Buch Weisbord, A Radical Life (Bloomington, IN, 1977); Dennis, The Autobiography of an American Communist; Mitford, A Fine Old Conflict; Junius Irving Scales and Richard Nickson, Cause at Heart: A Former Communist Remembers (Athens, GA, 1987; 2005).

34. Sivers, "Reflections on the Role of Personal Narrative".

35. "Seeing Red", directed by Julia Reichert and James Klein, (New York: New Day Films, I984).

36. Harry Haywood, Black Bolshevik: Autobiography of an Afro-American Communist (Chicago, IL, 1978); Painter, The Narrative of Hosea Hudson; Kenneth Kann, Joe Rappaport: The Life of a Jewish Radical (Philadelphia, PA, 198I); Steve Nelson, James R. Barrett, and Rob 
Given the strong bias for politics, what can these autobiographies tell us about the personal side of communist history? Acknowledging the bewildering array of human experience that confronts us in opening the subjective side of communist history, I have identified several realms that seem to exemplify the character of communist militants' personal lives: marriage and sexuality, child rearing and family life, and personal identity and crisis.

\section{LOVE AND MARRIAGE}

Though perhaps in somewhat different ways and with different feelings, many male and female radicals opposed marriage on political grounds. The discourse in the early Communist Party (1919-1929), especially among those men who came up through the Industrial Workers of the World (IWW) was one of virile, romantic revolutionary roughnecks, living in a rough-and-tumble dangerous capitalist world with little room for women. ${ }^{37}$ For Harvey O'Connor, who was not a member but remained close to the Communist Party for much of his adult life, marriage was "a bourgeois trap to hang a family on you, to enslave you to a steady job for the rest of your life, and to hell with it". As in patriarchal discourse more generally, women were seen as a burden on male revolutionaries. Recalling his attitude during his early years as a Wobbly,

Ruck, Steve Nelson, American Radical (Pittsburgh, PA, I98 I); Jessie Lloyd O’Connor, Harvey O'Connor, and Susan M. Bowler, Harvey and Jessie: A Couple of Radicals (Philadelphia, PA, 1988); Healey and Isserman, Dorothy Healey Remembers; Eugene V. Dennett, Agitprop, The Life of an American Working-Class Radical: The Autobiography of Eugene V. Dennett (Albany, NY, I992); Christina Looper Baker, In a Generous Spirit: A First-Person Biography of Myra Page (Urbana, IL, I996). For a perceptive discussion of the methods and context for this genre, see Roy Rosenzweig, "Oral History and the Old Left", International Labor and Working Class History,4 (1983), pp. 27-38. For the classic New Left formulation of the "personal is political", see Sarah Evans, Personal Politics: The Roots of Women's Liberation in the Civil Rights Movement and the New Left (New York, 1979); and for the roots of "second-wave feminism" in the Old Left, Kate Weigand, Red Feminism: American Communism and the Making of Women's Liberation (Baltimore, MD, 200I). On the tension between the Old Left activists' relentlessly political construction of their narratives and a New Left feminist's quest for the relationship between the political and the personal, see Trimberger, "Women in the Old and New Left", pp. $432-449$.

37. See Gosse, "To Organize in Every Neighborhood, in Every Home", and on the small number of women on the Party's central committee before the Popular Front years, Harvey E. Klehr, Communist Cadre: The Social Background of the American Communist Party Elite (Stanford, CA, 1978), pp. 70-82. For the masculinist subculture in the party, largely derived from the IWW and associated most closely with William Z. Foster, see James R. Barrrett, William Z. Foster and the Tragedy of American Radicalism (Urbana, IL, I999), pp. I I I-I I7; Palmer, James P. Cannon, p. 283. Brown and Faue, "Social Bonds, Sexual Politics, and Political Community in the US Left", and idem, "Revolutionary Desire: Redefining the Politics of Sexuality of American Radicals, I919-1945" represent the most substantial discussions of love and sexuality in the movement. 
O'Connor recalled, "Women restricted your movement without adding a great deal to your life." 38

Living together, however, was common, the writer Myra Page (Dorothy Markey) recalled, as were Russian liaisons for American communists. Indeed, the confessional anti-memoirs of autobiographers who left the party, the popular press, and postwar Hollywood anti-communist films all stressed communists' rampant sexuality as part of their threat to the American way of life. But, contrary to sensational representations concerning casual sex, particularly in the I920s, many party members disapproved. Earl Browder was living unmarried with one woman, Kitty, in China, but fell in love with Raissa in the USSR and lived with her there. Browder's rather turbulent love life was "shocking" to Page. Raissa had first fallen in love with party leader William Z. Foster and asked him to father the children she wanted, but Foster, a strict revolutionary ascetic, refused. "Foster had principles, especially about personal matters, and he refused because he had a wife", Page recalled. Browder, Raissa's second choice, accepted the offer. Page overstated her case, however, as Foster had at least one and possibly two lovers during his long marriage to Esther Abramovitz Foster. Again, communist attitudes and behavior were often vestiges of earlier movements. Both Foster and, especially, Esther had extended experiences with open relationships in the anarchist and syndicalist movements before ever joining the party, yet they established a life-long and, by most accounts, loving marriage. ${ }^{39}$

Theoretically, many communists believed in open relationships, what American anarchists had called "varietism". ${ }^{\circ}$ In real life this seldom turned out well. Working on a radical paper in Mexico with his wife Eleanor and another American radical, Charles Shipman soon came face to face with the contradictions between theory and practice. Early in their work, his wife Eleanor began an affair with the other comrade while the

38. O'Connor, O'Connor, and Bowler, Harvey and Jessie: A Couple of Radicals, pp. 48, I 26. 39. Baker, In a Generous Spirit, p. I 20. On Browder's domestic arrangements, see James G. Ryan, Earl Browder: The Failure of American Communism (Tuscaloosa, AL, I997), p. 32; on Foster's liaisons, Harvey J. Klehr, Communist Cadre, p. 72; Oliver Carlson interview with Harvey Klehr, 20-22 March 1978, p. 68, Harvey Klehr Papers, Special Collections, Robert W. Woodruff Library, Emory University; and Johanningsmeier, Forging American Communism: The Life of William Z. Foster, p. 324; and on Esther Abramovitz's experience, Hutchins Hapgood, The Spirit of Labor (New York, I907; repr. Urbana, IL, 2004), pp. 290-291; Lang, Tomorrow Is Beautiful, pp. 49, 78; Hutchins Hapgood, A Victorian in the Modern World (New York, 1939), pp. 196-207.

40. On "varietism", the early twentieth-century anarchist precursor to the Communist Party's free-love subculture of the 1920s, see Christine Stansell, American Moderns: Bobemian New York and the Creation of a New Century (New York, 2000), pp. 225-308. Maynes notes early and frequent sexual contacts in French and German working-class autobiographies. See Maynes, Taking the Hard Road, pp. I48-i 5 I. 
three of them were working together in a small office. "Theoretically libertarian in such matters, I was supposed to not care. But I did. Fiercely. When I insisted that it had to be him or me, she went to live with Clint. I thought I would never get over the loss of Eleanor". ${ }^{\mathrm{I}}$ While Dorothy Healey's second husband had been involved with other women "almost from the beginning" of their marriage and always reported these to her, she told herself and others it did not bother her, but it clearly did. When her third husband admitted that he was having an affair with another comrade's wife while Dorothy and the rest of the California leadership were on trial in the mid-I950s, Healey left him immediately. ${ }^{42}$

A lover hoping for romance, however, might be easily disappointed by a mate who was, above all, a professional revolutionary. Vera Buch Weisbord met and fell in love with her future husband Albert in the heat of the I925 Passaic textile strike, but it was hardly candlelight and soft music:

[D]uring a brief, quiet interval in the office, Albert drew me over to the window and as we stood close said in a businesslike way, "Smith, I want to live with you on a permanent basis, I believe you have the qualities I want in a partner. You have courage, intelligence, and the desire to be a Bolshevik".

Vera, herself a dedicated organizer, embraced these terms. "The word LOVE, so essential to me, had never once been uttered by him", she later wrote,

Now, however, he had put into words what must have been to him the highest praise. I realized that I had just received a proposal. Now I could really love my man without reservation; now I experienced not merely the joy and elation of being in love, but with it a deeply felt satisfaction never known before. ${ }^{43}$

Liaisons could be even more instrumental. Charles Shipman, working for the Comintern in Moscow, took up with a young Russian woman, Natalia Alexandrovna Mikhailova, though she seemed to be using him as much as he was her. "Natalie" was one of a "bevy of highborn young Russian women" working as auxiliary personnel at the Second Comintern Congress.

[She] spoke perfect English and had good handwriting. Moreover, she was a thing of beauty with stormy eyes set deep in her ivory face [...]. She was surprisingly ignorant $[\ldots]$ liked being around foreigners [...]. As might have been predicted, we began to sleep together. Jokingly, I asked her if she would like to go to Mexico with me. She said yes so fast that I gasped.

In order to be able to travel, he married her, making him a bigamist, as he still had a wife in the US. "Though I never had any deep feeling for

4I. Charles Shipman, It Had To Be Revolution: Memoirs of an American Radical (Ithaca, NY, I993), p. 80.

42. Healey and Isserman, Dorothy Healey Remembers, pp. 88, I45.

43. Weisbord, A Radical Life, pp. i I -1 16. 
Natalie, nor she for me, we enjoyed each other, she wanted to get out of Russia, and I trusted her." She was a "staunch, undemanding companion" for several years. ${ }^{44}$

The obvious chauvinism suggested by such an account is important to gauging the character of some personal relationships within the party. ${ }^{45}$ Such relationships often occurred between relatively younger, less experienced women and older male organizers, often their superiors. The adventurous quality of such affairs is undoubtedly important to understanding the women's motivation, but there is little doubt that difference in ages, experience, and status introduced an element of unequal power into the relationships. ${ }^{46}$ Shipman's story also conveys the cosmopolitan character of party activists who roamed the country and the globe, working in a wide range of environments with activists from diverse backgrounds in a worldwide political movement aimed at massive social, economic, and political transformation. The fact that most such activists came from working-class backgrounds suggests a particularly striking case of cosmopolitan experience that remains largely unexplored. To the extent that long-term sexual relationships were more open than typical marriages of the same era, this might have owed as much to this mobile lifestyle as to any particular ideological position regarding marriage or monogamy.

The instrumental approach to personal relationships suggested by Shipman's affair with Natalia could and did occasionally extend to the use of sex in the interests of party goals. 'My 'liberation' from conventional standards of female behavior did not consist so much of getting what I wanted in my private life", Dorothy Healey recalled, "as in not attaching a great deal of importance to what I was missing". As a young woman, after the end of her first marriage, Healey became involved with a succession of men and lived with a communist seaman for about two years,

$[\ldots]$ because I felt it was my Party duty to do it. [...] he was lonely and he was one of our best members and if that's what he wanted, and it's what he did want, then it was my Party duty [...]. Later, I started thinking of this as my "Salvation Army" approach to love and marriage. You're bestowing yourself because that's what somebody wants [...]. It shouldn't matter one way or the other. ${ }^{47}$

Communists clearly had models of love and marriage, often drawn from the history of the Russian revolution, before them. As Russian

44. Shipman, It Had To Be Revolution, pp. I 26, I 27.

45. Rosalyn Baxandall, "The Question Seldom Asked: Women and the CPUSA”, in Michael E. Brown, Randy Martin, Frank Rosengarten, and George Snedeker (eds), New Studies in the Politics and Culture of US Communism (New York, I993), pp. I4I-I62.

46. Carlson interview; Harvey Klehr, Communist Cadre, pp. $7 \mathrm{I}-73$.

47. Healey and Isserman, Dorothy Healey Remembers, p. 67. See also Brown and Faue, "Revolutionary Desire", pp. 284-285. 
personal and domestic lives were remade in the wake of the revolution, bourgeois observers often tended to exaggerate the more lurid aspects of these changes - notably, the notion that Soviet women's sexuality had been "collectivized". But change was real, nonetheless, in the areas of marriage, divorce, abortion, and other personal matters..$^{4}$ The new Soviet rulers were taken as models in their personal as well as their political lives. "You'll be my Krupskaya", Albert Weisbord promised in his proposal to his wife Vera.

You will go with me from one strike to another [...]. When we have the textile industry organized, we'll move on to steel, and so on, building the Party. You can never have children, not even a home. But you'll always be by my side, fighting with me, helping me $[\ldots] .^{49}$

When young communist labor organizers Joe and Sheba Rapaport decided to move in together before marriage, they were influenced by the USSR example as well as by hormones. "The new freedoms and new forms in the Soviet Union strengthened the idealism of radical young people here", Joe later recalled. "I didn't see the need for anybody, the government included, to give us permission to come together."

A stable marriage, whether formal or common law, was more typical among US communists than an open one, it seems, especially after the I930s. Earl Browder himself settled into a lifelong marriage and fatherhood of three children with Raiisa. A love affair that started casually in the heat of political struggles could persist a lifetime. The strength of such a union, as well as the domestic tensions it might produce, is suggested by the relationship between James Cannon and Rose Karsner, who began an affair while he was still married and both were raising children. Subject to the pressures of a revolutionary's life and trying to care for their children at a distance, Karsner and Cannon personify the problems of maintaining a family life in the party (and later in the Trotskyist movement). Yet they remained devoted to one another for life. ${ }^{5 \mathrm{I}}$ Myra Page's life might have been more typical than Browder's. She remained married to her "first love", John Markey, for sixty-six years, until his death.

We talked about it, but it never occurred to us to do anything but stay within traditional bounds. [...] throughout the sixty-six years of our marriage, John and I have been a team [...]. The partnership has been crucial. I don't believe

48. Ella Winter, Red Virtue: Human Relationships in the New Soviet Russia (New York, 1933). On the transformation in the personal lives of Russian women in the wake of the revolution, see also, Wendy Z. Goldman, Women, the State, and Revolution: Soviet Family Policy and Social Life, 1917-1936 (Cambridge, 1993).

49. Weisbord, A Radical Life, p. i 6.

50. Kenneth Kann, Joe Rapaport, p. 7r. See also Brown and Faue, "Revolutionary Desire", pp. 275-276; Winter, Red Virtue.

5. Palmer, James P. Cannon, pp. 195-196, 233-234, 313-315. 
I would ever have done it alone [...]. He's always been there - a strong person all the way through..$^{2}$

While they owed a great deal to political affinities, such pairings often crossed other boundaries, some of which seemed insurmountable in mainstream society. Interracial marriage, still extremely rare in the United States and actually outlawed in some states as late the r96os, suggests how the subculture of American communism diverged from the mainstream at this most intimate level as well as in more explicitly political ways. Indeed, as in other cases, the decision to marry across racial lines was a political choice made in the context of white supremacist ideology and practice. With no hard data, autobiographical information provides our only guide, but it appears that interracial marriage was certainly much more common within the CP than in the broader society. Important African-American leaders like William Patterson, Claudia Jones, Lovett Fort Whiteman, Abner Berry, and Harry Haywood all had white partners, while the Japanese-American activist, Karl Yoneda, married Elaine Black, a white communist organizer. The pressure that such couples undoubtedly felt was mitigated, it seems, within the communist subculture where such marriages were not only tolerated but nurtured. The black writer and poet, Claude McKay, recalled that as early as I 938 a group of black women communists in Harlem met to discuss the fact that most of the party's black male leaders had married white women (a practice that appears to have been more common than black women marrying white men). According to McKay, they drew up a resolution to Stalin and the Executive of the Communist International, protesting the practice. ${ }^{53}$

Correspondence during the McCarthy era between imprisoned communists and their families offers a rare glimpse of the personal relations between party spouses in the postwar era. Many letters concern mundane details of daily life in and out of prison, and the Smith Act prisoners clearly sought to maintain their roles as spouses and parents through such communication. Because the letters were censored coming into and going out of the prisons, it is perhaps not surprising that they contain little of a political nature, and they do occasionally convey details about defense work and other party matters. But they also suggest the strain that long jail sentences must have placed on the families of political prisoners and they convey above all the love between the correspondents.

"[...] I have been living from hour to hour every day," Aurelia Johnson wrote to her husband Arnold soon after he entered prison, "expecting you

52. Baker, In a Generous Spirit, pp. xviii-xix, 68, 75, 205. See also, Brown and Faue, "Revolutionary Desire”, pp. $285-286$.

53. See Erik McDuffie, "Long Journeys: Four Black Women and the Communist Party USA, 1930-1956" (unpublished Ph.D. dissertation, New York University, 2003), pp. 236-3 I 5; Karl Yoneda, Ganbatte: Sixty Year Struggle of a Kibei Worker (Los Angeles, CA, 1983). See also Weigand, Red Feminism, pp. 99-100. 
to come walking in [...]. It's good to read your letters sometimes as often as seven or eight times and I go back for a refresher every now and then [...]. Until tomorrow then - I shall close with love and thoughts of you always with me." "This morning I picked up your letter and my joy knew no bounds when I found the visit was being permitted", she wrote in March 1956, closing with "I love you and miss you so. I think of you and add the days. Lovingly always, Aurelia." 54 Arnold carefully counted each card and letter from his wife (I I 8 letters and I 87 cards in I955 alone, 333 messages of all sorts in 1956). He read them over and over again. $\mathrm{He}$ himself wrote the maximum number of letters allowable under prison regulations, always conveying his deep love for his wife and reminiscing often of past vacations and celebrations, often trying to place her in his mind's eye. ${ }^{55}$ Gil Green's children reported in detail on their school work, love lives, and neighborhood activities, and he often advised them on these and other matters. ${ }^{56}$ In many respects, he was simply trying to maintain his role as husband and father, though at a great distance.

Some aspects of private life were best kept separate from the political. While the CPUSA leadership was wary of recruiting gay members and gay communists often felt obliged to carefully separate their political and sexual lives, homosexual experiences were not uncommon and some evidence suggests that local party groups were more tolerant in this regard. Attitudes on the Left hardened, however, between the I920s and the postwar era, according to Kathleen Brown and Elizabeth Faue. The early twentieth century Left and I920s-era party were more open and tolerant of gay subcultures, while a less tolerant party culture was more common by the Popular Front era. The CPUSA leadership was particularly sensitive about the party's homosexual subculture during the McCarthy-era repression of the early i950s when considerable numbers of gay members were purged, ostensibly on security grounds. Even then, however, some local party leaders refused to expel trusted activists on the basis of sexual preference. Some activists in the emerging gay rights movements of the I960s, like Mattachine Society founder, Harry Hay, relied upon their communist organizing experience in establishing the basis for a an early gay rights movement. ${ }^{57}$

54. Aurelia Johnson to Arnold Johnson, 22 January I955; 5 March 1955, Box 2, Folder I8, Arnold Johnson Papers, Tamiment Institute, Bobst Library, New York University.

55. Arnold Johnson to Aurelia Johnson, I January 1956, Folder 21; I January 1957, Folder 23, Box 2, Johnson Papers.

56. Gil Green Papers, Box I, Chicago Historical Society. See also the prison correspondence between Fred Fine and his wife Doris, Fred Fine Papers, Series I, Chicago Historical Society. 57. Brown and Faue, "Revolutionary Desire: Redefining the Politics of Sexuality of American Radicals, I919-1945", pp. 287-293; idem, "Social Bonds, Sexual Politics, and Political Community", pp. 32-34; Healey and Isserman, Dorothy Healey, pp. I29-I30; John D’Emilio, Sexual Politics, Sexual Communities: The Making of a Homosexual Minority in America (Chicago, IL, I984), 


\section{CHILDREN AND ABORTION}

In the context of a revolutionary party, particularly in periods of repression or revolutionary crisis, the decision to have children was even more complex than it would normally be and, again, the stakes were rather different for male and female activists. In the I920s and early Depression years, many party leaders actively discouraged the idea of raising children in the midst of trying to make a revolution. While such thinking was undoubtedly nurtured in the shadow of Soviet mythology, it was not born with the Communist Party. William Z. Foster clearly carried over from syndicalist days the principle that children inhibited militants and "provided a new supply of slaves” for capitalists. Harvey O'Connor, another Wobbly veteran, also refused to have children. He married a young socialist woman reluctantly and for largely practical reasons, but he "emphasized that I wanted no children and would not be tied down for the rest of my life. Love being what it is, Blanche agreed even to the point, eventually, of having a hysterectomy." When O'Connor succumbed to the idea of children in his second marriage to Jessie Lloyd, it was less an enthusiastic conversion than a negotiated concession: "Well, that is the way women are and you have to humor them." ${ }^{8}$ But such feelings were widespread especially during the I920s and early I930s. "Among the Left, women as active as I was were not expected to have children", Myra Page recalled, "women were scarce, and those willing to work as leaders needed to put in their time [...] you made a choice." Again, the Soviet experience was invoked as a model, though more than one lesson could be drawn. Seeing activist mothers in the USSR emboldened Myra Page to have children of her own. ${ }^{59}$

Elizabeth Gurley Flynn's mother and sister cared her for her son Fred during her extended speaking and organizing tours, first for the IWW and later for the Communist Party. One of the few regrets she recalled in her copious autobiographical writings concerned her long absences from her only son Fred. "I recall a Christmas Eve, I919, walking through Union Square, white with snow, with [...] the attorney who represented many of the Russian deportees, and realizing suddenly that I should be home, filling my child's stocking instead attending a meeting."60

The extent to which the international communist movement might intrude on family life and the rearing of children - and the extent to which

pp. 58-70; "The Founding of the Mattachine Society: An Interview with Henry Hay," Radical America, I I (July-August 1977), pp. 29, 32, 34.

58. O’Connor, O’Connor, and Bowler, Harvey and Jessie, pp. 48, 206.

59. Baker, In a Generous Spirit; Earl Ford and William Z. Foster, Syndicalism (Chicago, IL, I91 2; repr. Chicago, IL, I998), p. I7.

60. Elizabeth Gurley Flynn, Rebel Girl: An Autobiography, My First Life (1906-1926) (New York, 1973), p. 266. Flynn had not yet joined the CPUSA at the time of the experience. 
party parents might go in following party directions - is suggested by the experience of Eugene and Peggy Dennis in the early i930s. While he was sent on Comintern work to South Africa, the Philippines, and China, she was sent to various points in Europe, and their four-year-old son, Tim, was placed in the Comintern Children's Home for almost two years. Here he lived with the children of revolutionaries sent on Comintern missions around the world. By the time they returned, Tim spoke only Russian and Comintern leaders feared that he would represent a security risk - for the international movement and the CPUSA - on the trip back and during his early months in the US. They ordered the parents to return home without their son who would be sent back at some other time, "under different circumstances". Peggy Dennis recalls the anguish she felt in this situation, but the parents themselves made the decision to leave their firstborn son in the USSR where Tim would be "safe, protected, given the best socialism had to offer". Tim remained in the Soviet Union for the rest of his life and saw his parents only a couple of times over the next two decades. ${ }^{61}$ As difficult as this decision may be to understand, it does help to explain the resolve of some communists to avoid the responsibility of raising children - even when that meant abortion.

Diaphragms and other forms of birth control were likely even more common in the communist movement than in other areas of American life by the I920s, but so were accidents and, as a result, abortions. ${ }^{62}$ Dorothy Healey sustained a series of three abortions and at least one miscarriage during her early years in the party. "It was just taken for granted that we would have abortions. Who could think of a revolutionary having a child?" ${ }_{3}$ When Vera Buch became pregnant in the midst of her organizing of the 1929 Gastonia strike, her lover and future husband, Albert Weisbord, insisted that she get an abortion because "the inconvenience would be great if we wanted to be active revolutionaries". He refused to accompany her, however, insisting that paying for the procedure was his only responsibility. Following a botched abortion by an amateur, Buch suffered as much emotionally as physically: "Something very strong and primitive in me had been violated [...]. Behind it all was resentment at what seemed to be Albert's callousness. Why had he refused to go there with me? Is it possible to love and feel no concern for the loved one?"64

6r. Dennis, Autobiography of an American Communist, pp. 77-87, quotations, pp. 86, 87 .

62. Leslie Reagan establishes that birth control practices and abortion were both rather more widespread in the United States than we often imagine. See Leslie J. Reagan, When Abortion Was a Crime: Women, Medicine, and Law in the United States, 1867-1973 (Berkeley, CA, 1997).

63. Healey and Isserman, Dorothy Healey Remembers, p. 87, quotation, p. 38. See also, Hooper, In a Generous Spirit, p. I 36.

64. Weisbord, A Radical Life, pp. I67, I68-169. 
Ironically, given this attitude toward children, party cadres often employed a family metaphor to explain the strength of personal bonds within the movement. "In some ways the Party was like a family", Myra Page recalled. "We formed very close relationships, but then we fought like families when we thought something was important enough [...]. We lost friends when we left. It was sad and painful." ${ }^{65}$

Party attitudes toward children seem to have loosened up during and immediately after the World-War-II era in the midst of the baby boom. It might also make a difference, it seems, whether one was dealing with male or female leaders. In 1943, when Dorothy Healey decided she wanted a child, she asked her California state party secretary, and Oletta O'Connor Yates, county organizer in San Francisco, what they thought. Both agreed readily, though Healey admitted that if they had not done so, "I would have heeded party discipline and foregone the pregnancy." 66

Peggy Dennis observed a close relationship between the domestic burdens of women activists and their small representation among the leadership cadres. Many who reached such heights had neither children nor a permanent personal relationship. "To comply with the methods governing party work, a woman had to be willing to relegate the children to an around-the-clock surrogate parent." ${ }^{\prime 67}$ Dorothy Healey was determined that her son would not become such a "party orphan". Her mother assumed day-care duties when Healey had to be out of town. She insisted on leaving the party office at 3.30 everyday to pick Richard up from child care, often held meetings at her home to avoid leaving him in the evening, and left meetings to answer his call and talk to him as he fell asleep. ${ }^{68}$ But many activists became part-time parents because they remained full-time revolutionaries. Harvey and Jessie O'Connor left their children with caregivers daily and for extended periods of time. ${ }^{69}$

Some of the slack might be taken up by the various youth activities sponsored by communist parties throughout the world - sports programs and summer camps, the Young Pioneers, and relationships with other children in the party. As Deborah Gerson recalls in an autobiographical

65. Baker, In a Generous Spirit, p. 187. On the notion of an extended family that appears in many autobiographies, embracing close friends throughout the party and sometimes crossing national boundaries, see Brown and Faue, "Social Bonds, Sexual Politics, and Political Community", pp. I $5-16$.

66. Healey and Isserman, Dorothy Healey Remembers, p. 88. Most members of the party's National Board in the postwar era were married with children.

67. Peggy Dennis, "A Response to Ellen Kay Trimberger's Essay, 'Women in the Old and New Left", Feminist Studies, 5 (1979), p. 453, quoted in Deborah Gerson, "Is Family Devotion Now Subversive? Familism Against McCarthyism", in Joanne Meyerowitz (ed.), Not June Cleaver: Women and Gender in Postwar America, 1945-1960 (Philadelphia, PA, 1994), p. 170.

68. Healey and Isserman, Dorothy Healey Remembers, p. 89.

69. O'Connor, O’Connor, and Bowler, Harvey and Jessie, p. 207. 
article, "in summer camp we lived out the Left's values [...] camp became the locus of our emotional relationships". The camp was a "respite" from the burden of living as part of a small political minority in an overwhelmingly hostile environment. ${ }^{70}$ The demanding character of party membership and a very conscious effort to instruct members on "how to bring up communist children" undoubtedly shaped child-rearing. A striking array of children's publications, summer camps, and youth groups sustained a communist culture among the party's youth. ${ }^{7 \mathrm{I}}$

Given all this, children's experiences varied enormously from one family to another, judging from the personal narratives of "red-diaper babies". Some remembered their communist childhoods fondly; others recalled being neglected in the interests of political activity. Stephanie Allan's communist parents were careful to bring the family together for dinner every evening before the regular round of meetings, to save weekend time for the family from their busy political lives, and to bring children whenever they could to demonstrations and rallies so that the family would be together. She recalls hers as a "warm, loving family life". ${ }^{2}$ But other red-diaper babies remember great distance from their parents.

Maxine DeFelice was verbally attacked almost daily and later raped by a gang of boys, but her parents seemed always to be in meetings and she felt unable to confide in them. "No one knew, no one noticed", she recalled. "Important things were happening." Living in North Carolina, where her parents were CIO union organizers, she found solace as the only white member of a black church. ${ }^{73}$ Other children felt abandoned when their parents were imprisoned or sent underground during the McCarthy era. The most striking of the "red-diaper" autobiographies may well be Bettina Aptheker's. ${ }^{74}$ While most commentators have focused on the author's charges of sexual abuse at the hands of her father, however,

70. Gerson, "Is Family Devotion Now Subversive?", pp. I61, I62. On the importance of leftwing summer camps and other children's activities in sustaining party children in the midst of the McCarthy era, see Peggy Dennis's recollections regarding her son Gene in Autobiography of an American Communist, p. I87, and the reminiscences of Peggy Dennis, Sirkka Tuomi Holm, Mary Louise Patterson, and others in Kaplan and Shapiro, Red Diapers. See also, Paul Mishler, Raising Reds: The Young Pioneers, Radical Summer Camps, and Communist Political Culture in the United States (New York, 1999).

7I. On party admonitions and prescriptions, see Kaplan and Shapiro, Red Diapers, pp. 5-6, and on party youth culture, Mishler, Raising Reds; Julia L. Mickenberg, Learning from the Left: Children's Literature, the Cold War, and Radical Politics in the United States (New York, 2006). 72. Kaplan and Shapiro, Red Diapers, p. I20. Vivian Gornick evokes the exhilaration of growing up in the Communist Party milieu in Romance of American Communism, pp. $3^{-1} 2$.

73. Kaplan and Shapiro, Red Diapers, pp. 91-92, 7-I I, quotation, p. 92.

74. Bettina F. Aptheker, Intimate Politics: How I Grew Up Red, Fought for Free Speech, and Became a Feminist Rebel (Emeryville, CA, 2006). 
the story's main theme seems to be the daughter's efforts to frame her own identity and politics in the shadow of her father Herbert Aptheker, a pioneer scholar of African-American history and one of the party's main intellectual figures.

Living within the party could put enormous pressure on children, particularly in periods of political repression. On the night the Rosenbergs were executed, ten-year-old Gene Dennis awoke screaming with a fear shared by other children in communist families: "I don't want to die! They will kill him too. Bring my Daddy home; they will kill him too." His mother too had nightmares she shared with no one. "At night", she wrote at the time, "we each weep and surrender to the fears that grip our lives". ${ }^{75}$ Particularly today, when revisionists are rehabilitating the image of McCarthyism, such accounts help us to grasp the damage wrought at the neglected personal level in this era of severe political repression. ${ }^{76}$

\section{POLITICAL CRISIS AS PERSONAL CRISIS}

The notion that communists were selfless conveys something of the quality of the political commitment and its implications for one's personal life, but it also reinforces the perception of communists as the other, people strangely different from us. The striking silence on personal issues in most Communist Party autobiographies was not only the product of design or conscious choice. It was also shaped by a very different understanding of the personal. In fact, many communists explained their commitments in terms of a particular kind of self-realization which was intense and fulfilling but also tended to subsume the personal in the political. This latter characteristic hobbled individual members and the party as an organization in trying to deal with serious personal problems. The pressure of daily communist political activity, let alone the sort of

75. Dennis, Autobiography of an American Communist, pp. 2 I 0 , 2 I I. Not surprisingly perhaps, the execution of Julius and Ethel Rosenberg, both accused of passing on secrets regarding atomic bomb research to the Soviets, appears as a central trope in the narratives of many Red Diaper Babies. See, for example, the recollections of Dorothy Zellner (pp. 85-87), and Rachel Fast Ben-Avi (p. I3I), and for explicit fears that their parents too would be arrested and executed, see the recollections of Stepahine Allan (p. I 18), and Bettina Aptheker (p. 284), all in Kaplan and Shapiro, Red Diapers.

76. Ethan Bonner, "Witching Hour: Rethinking McCarthyism, if not McCarthy", New York Times, I 8 October 1998, section 4, pp. I, 6 summarizes the scholarship and some of its effects in terms of a rehabilitation of McCarthy-era anti-communism. By far the most popular account is Ann Coulter's bestseller, Treason: Liberal Treachery from the Cold War to the War on Terrorism (New York, 2003), which relies on the works of John Earl Haynes, Harvey Klehr, and other historians of the CPUSA, and includes references to coverage of this issue in the popular press. For a major anti-communist reinterpretation of the McCarthy era in light of the Russian archival material, see John E. Haynes, Red Menace or Red Scare? American Communism and Anticommunism in the Cold War Era (Chicago, IL, I996). 
extreme stress to which communist men, women, and children were subject during the McCarthy era, produced numerous such personal crises which remain largely unexplored.

Diane, an accomplished Broadway actress who left the party after fifteen years of strong commitment, recalled the personal fulfillment she experienced during her time as a communist.

They were good years, very good years. Richly alive with the sense of everything coming together, a fusion of world and being that made you drunk with life [...] my life has been a long journey into myself. My years as a communist taught me things about human identity I would never have realized otherwise.

Yet she regretted "the tragedy of identifying your entire self with anything outside of yourself". ${ }^{77}$ When she faced an emotional crisis in the postwar period, her comrades were ill prepared to lend support, or even to understand what was happening.

[...] something began to happen inside of me [...] imperceptibly, without my knowing it consciously, things began to come apart for me in the Party [...]. I struggled desperately to let them know what was happening to me [...]. They didn't know what I was talking about [...] this was all personal and, therefore, trivial $[\ldots]$ I should be more serious [...] it was wrong to be so concerned with something as frivolous as my feelings [...]. I saw more and more that these people, my comrades, did not know themselves what they actually thought and felt [...]. Their identification with the Party had become so complete, so absolute, they no longer knew the difference between their own finite selves and what I could now only call Party dogma. I felt terribly lost. Who was I? What was I? Why was I here? What did it all mean ?[...] The very fact that in the Party everything personal was suppressed and despised began to make it impossible for me to ignore the personal [...] if they had been clever enough to give me even a bit of understanding, I might have remained a communist for God knows how long. ${ }^{78}$

This emotional poverty appears most often in autobiographies in the context of political and personal crisis, for the two often went together. For Peggy Dennis, who spent more than forty years in the party, the moment came during the Smith Act trials when the entire party leadership, including her husband Eugene Dennis, was indicted and eventually imprisoned. Of the eleven defendants, one, Elizabeth Gurley Flynn, was an unmarried woman whose adult son had died earlier. Most of the rest left wives and families behind as they entered either prison or underground lives on the run. The party itself was completely preoccupied with

77. Gornick, Romance of American Communism, pp. 230, 233. Even many of the autobiographies and interviews of those who left the movement over the years contain similar statements.

78. Ibid., p. $23 \mathrm{I}$. 
defense work and in preparing the organization for what the leading faction saw as the imminent rise of fascism in the United States. "With husbands gone and the Party organization we had always relied on absent", Dennis recalled, "living with insurmountable family problems and fears and apprehensions, we were thrown upon our own resources and upon each other". ${ }^{79}$

These communist wives and mothers created the Families Committee of Smith Act Victims to support the prisoners and their children and to educate the public on the threat to civil liberties represented by the sweeping legislation under which the party was suppressed. In an era of hyper-domesticity and extreme nationalism, red-diaper baby Deborah Gerson notes, they adopted the language of family values to make their case. Women activists were doubtless influenced by a new postwar cult of domesticity, but it was also a political strategy. More than the constitutional issues involved in their cases, the Committee's propaganda featured photos of the defendants with their families and emphasized their domestic roles as parents and spouses. ${ }^{80}$ Writing in behalf of the Smith Act defendants in the spring of 1956, W.E.B. DuBois conceded that some Americans "believe that these victims have endangered this nation by what they have thought and said". "But I think that all of us can agree on one thing", he concluded, "and that is that the families and children of these persons should not be made to suffer". ${ }^{81}$

Many of these women were skilled and hardened political organizers. Their movement achieved some of its limited aims and provided extensive material and political support for the families, but few of them credited the committee with providing the day-to-day emotional support required to get through the crisis. Peggy Dennis recalls that

As to the personal problems each of us had, none of us was equipped by our Party experience to respond to each other on a simple human level [...] we had no experience in the Party to respond to each other as individuals, only in impersonal political concepts [...]. Like the other wives, officially and outwardly I was too calm, too impersonal, too political. Within myself, I cried silently. ${ }^{82}$

"In the CP there was no space for feelings as such", writes Deborah Gerson who lived through the ordeal as a child. The party "placed no

79. Dennis, Autobiography of an American Communist, p. 2 I 5.

80. See, for example, "The Story of Junius Scales, Southerner" (New York, late 1956); "Newsletter from Peggy Wellman", 22 February 1957, and the pamphlet attached to "Dear Friend" from Families of the Smith Act Victims, 28 June 1956, with photographs of the Henry Winston, Gil Green, Fred Fine, William Norman, and James Jackson families, all materials in Arnold Johnson Papers, Box 2, Folder 24, Tamiment Institute, Bobst Library, New York University. On the strength of domestic ideology in the context of the Cold War, see Elaine Tyler May, Homeward Bound: American Families in the Cold War Era (New York, 1988).

81. W.E.B. DuBois to "Dear Friend", 20 June 1956, Johnson Papers, Box 2, Folder 24.

82. Dennis, Autobiography of an American Communist, p. 2 I s. 
special value on the expression of one's own feelings; focusing on personal upsets bore the stigma of 'subjectivity' and was disdained". ${ }_{3}$

Whatever practical support the party provided its members, some of them felt this emotional deficit keenly. Diane, the actress quoted above, experienced her personal crisis in the context of McCarthy-era political repression, divorce, unemployment, and a call to testify before the House Un-American Activities Committee (HUAC). "My husband, the Party, my work - everything went up in smoke in one hideous moment." ${ }^{84}$ She called the talented professional revolutionaries with whom she worked "politically astute, emotionally ignorant". ${ }^{85}$ Another Communist Party veteran, a well known editor, also noted what he called the "emotional distance" that "grew up between me and the world beyond the Party". ${ }^{86}$

While the McCarthy era was a particularly striking period of stress produced by political isolation and repression, one might well identify other situations in which such considerations are relevant to communist history - the extreme factionalism of the late I920s and I940s when hundreds of people were driven out of the movement; the bitter class warfare of the early Depression "Third Period"; the declaration of the Hitler-Stalin Pact which derailed the Party's vibrant anti-fascist movement at a stroke; Khrushchev's excruciating 1956 litany of Stalin's crimes which shattered the lifelong political commitments of thousands of individuals. In this sense the personal side of the communist experience has a bistory every bit as much as its more public dimensions.

Life within the movement was often intense and personal relationships might be quite intimate, but emotions were experienced and relationships developed through the political life of the party. A university physicist who had started a new life after twenty years in the movement came to realize that his "deepest emotions are engaged only in a political context [...]. Our political life is so deeply intertwined with our personal life [...]. It is our personal life. I mean, I'm not sure what else there is [...] apart from politics." 87 "For sixteen years", another veteran recalled, "I was suffused with the dogma of Communism [...]. My studies, my marriage, my friendships were all strained through the liquid flow of Marxist thought before they entered my brain and my feelings." Vivian Gornick emphasizes the passion of American communists, what she calls "this hook upon the soul", that invested the lives of militants with far more drama than those of most working people. ${ }^{88}$

83. Gerson, "Is Family Devotion Now Subversive?", p. I69.

84. Gornick, Romance of American Communism, p. 232.

85. Ibid., p. 233.

86. Ibid., p. 239.

87. Ibid., pp. $247^{-248 .}$

88. Ibid., p. I3. 
What was most striking to Gornick in more than forty interviews with veteran communists, however, was the high development of what she termed "the gift for political emotion", while "the gift for individual sympathy" was "neglected, atrophied [...] the experience of all things human lives primarily through the political act". Thus, as Gornick notes, a deep irony resides at the heart of communist history, for the same passion that plunged individual communists into this intense emotional experience also produced what she calls "a dogmatic purging of the self" ${ }^{89}$ When an interviewer pursued details about William Z. Foster's private life, his subject resisted. "The movement", Foster concluded "is the decisive matter". ${ }^{\circ}$

\section{CONCLUSION}

The conventions and exigencies of life in the movement discouraged American communists from expressing their personal feelings and shaped the character of personal relationships. The more revealing autobiographies and interviews suggest a connection between this particularly (some might say peculiarly) strong political commitment and the subjective dimensions of one's life. Yet the distance most historians have placed between themselves and these historical subjects has warped our view of this history.

Communist autobiography, even more than most working-class autobiography, reflected a view of the world and a particular kind of political commitment that militated against the kind of introspection and subjectivity we might expect to find in this most intimate form of writing. Given the sort of an organization to which they belonged and the very different political contexts within which they operated, this is not surprising. But this does not mean that party members lacked personal lives, or that these lives are superfluous to our understanding their movement. Even the self-realization that is the stuff of autobiography is present in some of these texts, particularly in the narratives of women activists, though perhaps in a form that appears strange to us.

While male autobiographers might concentrate entirely on the political, writing as if they had no personal lives, women's memoirs are far more apt to include personal details. Subject to the chauvinism that penetrated their movement, as it did other realms of American society, communist women faced a double standard in their personal as well as their political lives. Nor, despite their political activism, did they escape the gender norms of their times. As a result, their narratives provide rare glimpses and often insightful reflections on family life, personal relationships, and self realization through political activism.

89. Ibid., p. 248. The passion and self-realization achieved through life in the movement and the failure to make a place for the individual within this world is the central theme of Gornick's book. 90. Douglas, Six Upon the World, p. I I9. 
The lesson here is not that the personal was more important than or even equal to the political but that the former can help us to understand the latter. Communist autobiographies suggest, for example, that selfrealization came through collective experience and party activity, an extreme version perhaps of the collective quality scholars have found in working-class narratives more generally. We find not only a politically charged context but also a fusion of the personal and the political in these life stories that is distant from our own conservative political climate and our radically depoliticized lives. But perhaps this distance from our own experience represents another characteristic that makes the study of such lives important - for political as well as historical reasons.

Serious consideration of the personal dimensions of communist activism provides a very different perspective on two important recent trends in the history of the United States. The first is an increasing tendency in revisionist literature to see the CPUSA largely as an arm of the Soviet Union and to diminish its role as a social movement, particularly at the local level in cities and town throughout the United States. Some American communists clearly did operate as espionage agents and the American party's subservient relationship to the Soviet party distorted its programs and political judgment. The second tendency in the historiography follows from this characterization. By focusing particularly on Soviet espionage work in the US some historians have justified the enormous damage done in the McCarthy era. Since it is clear now that many individual American communists were involved in such work, the tendency is to excuse the political repression of those years as a necessity for guarding national security.

An autobiographical approach not only underscores the emotional strain brought to bear on individual radicals and their families during such periods of repression. It also begins to suggest the fit, or lack of one, between personality, personal relationships, and emotions on the one hand and particular types of political organizations and policy on the other. Specifically, the patriarchal character of Stalinist parties like the CPUSA left little role for personal expression and identity - even less for women members than it did for men.

At its broadest level, the autobiographical approach to American communism suggests a level of experience that has remained largely submerged in labor history - for the US and other societies. It encourages us to consider radicals and other working people, not simply as members of a particular social class or participants in social movements, but also as individuals with personalities and private lives, each with his or her own strengths and frailties, that may have shaped their motivations and behavior beyond the political and social forces we find to be more familiar in our work. In this sense autobiography affords a different angle not just on the history of the international communist movement but also on the historical experience of working-class people more generally. 